\title{
Neuroblastoma-Amplified Sequence
}

National Cancer Institute

\section{Source}

National Cancer Institute. Neuroblastoma-Amplified Sequence. NCI Thesaurus. Code C33961.

Neuroblastoma-amplified sequence (2371 aa, $269 \mathrm{kDa}$ ) is encoded by the human NBAS gene. This protein is involved in retrograde (Golgi-to-endoplasmic reticulum (ER)) transport of intracellular vesicles. 